This document was prepared in conjunction with work accomplished under Contract No. DE-AC09-96SR18500 with the U. S. Department of Energy.

\title{
DISCLAIMER
}

This report was prepared as an account of work sponsored by an agency of the United States Government. Neither the United States Government nor any agency thereof, nor any of their employees, nor any of their contractors, subcontractors or their employees, makes any warranty, express or implied, or assumes any legal liability or responsibility for the accuracy, completeness, or any third party's use or the results of such use of any information, apparatus, product, or process disclosed, or represents that its use would not infringe privately owned rights. Reference herein to any specific commercial product, process, or service by trade name, trademark, manufacturer, or otherwise, does not necessarily constitute or imply its endorsement, recommendation, or favoring by the United States Government or any agency thereof or its contractors or subcontractors. The views and opinions of authors expressed herein do not necessarily state or reflect those of the United States Government or any agency thereof. 


\section{NEPHELINE FORMATION POTENTIAL IN SLUDGE BATCH 4 (SB4) GLASSES}

D.K. Peeler

T.B. Edwards

T.H. Lorier

April 2005

Immobilization Technology Section Savannah River National Laboratory Aiken, SC 29808 
WSRC-TR-2005-00153

Revision 0

\section{DISCLAIMER}

This report was prepared by Westinghouse Savannah River Company (WSRC) for the United States Department of Energy under Contract No. DE-AC09-96SR18500 and is an account of work performed under that contract. Neither the United States Department of Energy, nor WSRC, nor any of their employees makes any warranty, expressed or implied, or assumes any legal liability or responsibility for the accuracy, completeness, or usefulness, of any information, apparatus, or product or process disclosed herein or represents that its use will not infringe privately owned rights.

Reference herein to any specific commercial product, process, or service by trademark, name, manufacturer or otherwise does not necessarily constitute or imply endorsement, recommendation, or favoring of same by WSRC or by the United States Government or any agency thereof. The views and opinions of the authors expressed herein do not necessarily state or reflect those of the United States Government or any agency thereof.

Printed in the United States of America

Prepared For

U.S. Department of Energy 
Key Words: durability, crystallization, residual glass matrix effects

Retention: Permanent

\title{
NEPHELINE FORMATION POTENTIAL IN SLUDGE BATCH 4 (SB4) GLASSES
}

\author{
D.K. Peeler \\ T.B. Edwards \\ T.H. Lorier
}

April 2005

Immobilization Technology Section Savannah River National Laboratory Aiken, SC 29808 


\section{REVIEWS AND APPROVALS}

\section{AUTHORS:}

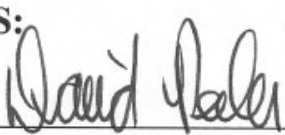

$5-5-05$

D. K. Peeler, Immobilization Technology Section

Date

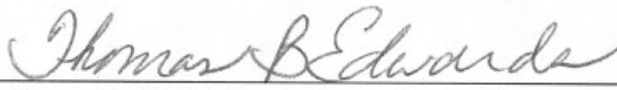

T. B. Edwards, Statistical Consulting Section

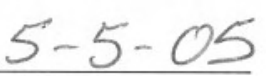

\section{TECHNICAL REVIEWER:}

conne i torman

C.C. Herman, Immobilization Technology Section
$5-10-05$

APPROVERS:

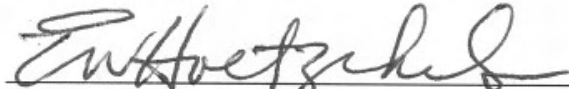

E. W. Holtzscheiter, Manager, Immobilization Technology Section

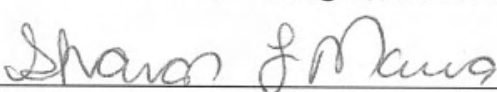

S. L. Marra, Manager, Glass Formulation \& Process Development

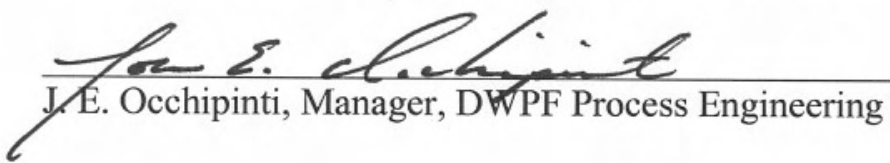

$5-(0-0)$

Date

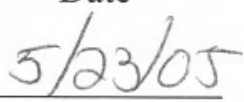

Date

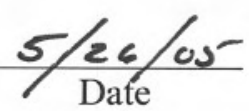


WSRC-TR-2005-00153

Revision 0

\section{Executive Summary}

The effect of crystallization on glass durability is complex and depends on several interrelated factors including the change in residual glass composition, the formation of internal stress or microcracks, and the preferential attack at the glass-crystal interface. Perhaps one of the most significant effects is the type and extent (or fraction) of crystallization and the resulting change to the residual glass composition. A strong increase in glass dissolution (or decrease in durability) has been observed in previous studies in glasses that formed aluminum-containing crystals, such as $\mathrm{NaAlSiO}_{4}$ (nepheline) and $\mathrm{LiAlSi}_{2} \mathrm{O}_{6}$, and crystalline $\mathrm{SiO}_{2}$.

Although the addition of $\mathrm{Al}_{2} \mathrm{O}_{3}$ to borosilicate glasses enhances the durability of the waste form (through creation of network-forming tetrahedral $\mathrm{Na}^{+}-\left[\mathrm{AlO}_{4 / 2}\right]^{-}$pairs), the combination of high $\mathrm{Al}_{2} \mathrm{O}_{3}$ and $\mathrm{Na}_{2} \mathrm{O}$ can lead to the formation of nepheline $\left(\mathrm{NaAlSiO}_{4}\right)$. Given the projected high concentration of $\mathrm{Al}_{2} \mathrm{O}_{3}$ in SB4 and the potential use of a high $\mathrm{Na}_{2} \mathrm{O}$ based glass (as a result of the use of a high $\mathrm{Na}_{2} \mathrm{O}$ frit and/or a less washed sludge) to improve melt rate, the potential formation of nepheline in various SB4 systems is being assessed.

Li et al. (2003) indicate that sodium alumino-borosilicate glasses are prone to nepheline crystallization if their compositions projected on the $\mathrm{Na}_{2} \mathrm{O}-\mathrm{Al}_{2} \mathrm{O}_{3}-\mathrm{SiO}_{2}$ ternary fall within the nepheline primary phase field. In particular, durable glasses with $\mathrm{SiO}_{2} /\left(\mathrm{SiO}_{2}+\mathrm{Na}_{2} \mathrm{O}+\mathrm{Al}_{2} \mathrm{O}_{3}\right)>0.62$, where the oxides are expressed as mass fractions in the glass, do not precipitate nepheline as their primary phase.

Twelve SB4-based glasses have been identified or classified as "prone to nepheline formation” using a "less conservative" discriminator value of 0.65 . Ten of the 12 glasses are Frit 320 based, and 8 of these 10 target a $40 \% \mathrm{WL}$ - independent of the SB4 blending scenario used. This is not unexpected due to the higher alkali content of Frit $320\left(12 \% \mathrm{Na}_{2} \mathrm{O}\right)$ relative to Frit $418\left(8 \% \mathrm{Na}_{2} \mathrm{O}\right)$ and the fact that as WLs increase, the $\mathrm{Na}_{2} \mathrm{O}$ and $\mathrm{Al}_{2} \mathrm{O}_{3}$ concentrations increase and the $\mathrm{SiO}_{2}$ concentrations decrease in this series of glasses. Using the "less conservative" value as a guide will not only increase the probability of forming nepheline but will also allow the assessment of several different blending scenarios, both frits, and different WLs which will provide valuable insight into the frit selection process for SB4. More specifically, blending strategies, frit compositions, and WLs that avoid nepheline formation could be used to guide the frit selection process or to make compositional adjustments to the frit. The durability of these 12 glasses (of both quenched and centerline canister cooled versions) will be measured with the results being documented in a subsequent report. 


\section{TABLE OF CONTENTS}

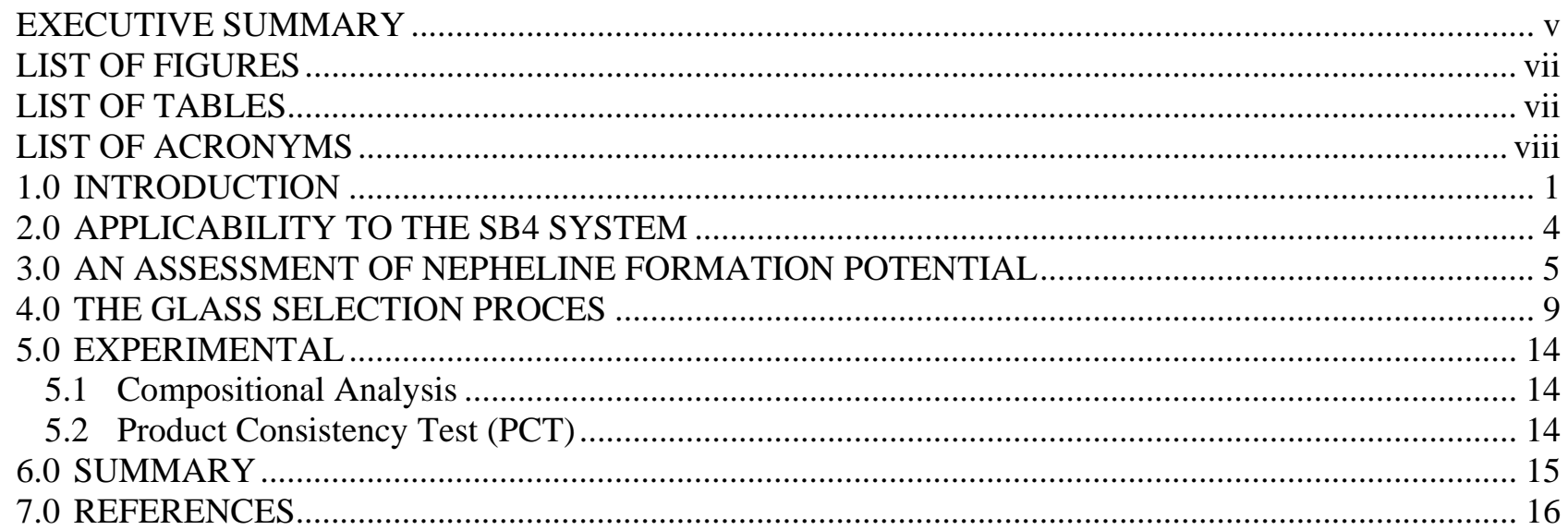


WSRC-TR-2005-00153

Revision 0

\section{LIST OF FIGURES}

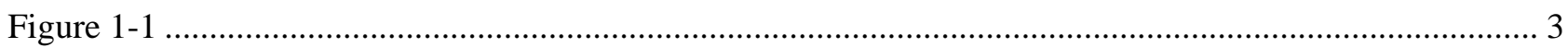

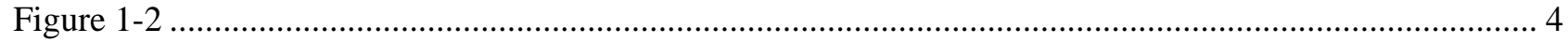

\section{LIST OF TABLES}

Table 3-1 Compositions of Select Glasses from the SB4 Glass Systems (Part 1: $\mathrm{Al}_{2} \mathrm{O}_{3}$ through MnO)........ 7

Table 3-2 Compositions of Select Glasses from the SB4 Glass Systems (Part 2: $\mathrm{Na}_{2} \mathrm{O}$ through $\left.\mathrm{ArO}_{2}\right)$..........8

Table 4-1 The 48 SB4 Glasses as a Function of WL, Frit ID, Sludge Type and Nepheline Ratio ................ 10

Table 4-2 Target Glass Compositions (in wt\%) for the NephelineFormation Study (Neph-01 through Neph-06)....

Table 4-2 (continued) Target Glass Compositions (in wt\%) for the Nepheline Formation Study (Neph07 through Neph-08) 


\section{LIST OF ACRONYMS}

$\begin{array}{ll}\text { ARM } & \text { Approved Reference Material } \\ \text { ARP } & \text { Actinide Removal Process } \\ \text { ASTM } & \text { American Society for Testing and Materials } \\ \text { cCC } & \text { centerline canister cooled } \\ \text { CVS } & \text { composition variation study } \\ \text { DWPF } & \text { Defense Waste Processing Facility } \\ \text { EA } & \text { Environmental Assessment } \\ \text { HLW } & \text { high-level waste } \\ \text { ICP-AES } & \text { Inductively Coupled Plasma - Atomic Emission Spectroscopy } \\ \text { LM } & \text { lithium metaborate } \\ \text { MCC } & \text { Materials Characterization Center } \\ \text { NL [B] } & \text { normalized boron release (in g/L) } \\ \text { PCT } & \text { Product Consistency Test } \\ \text { PF } & \text { peroxide fusion } \\ \text { SB } & \text { sludge batch } \\ \text { SRL } & \text { Savannah River Laboratory } \\ \text { SRNL-ML } & \text { Savannah River National Laboratory - Mobile Lab } \\ T_{L} & \text { liquidus temperature } \\ \eta & \text { viscosity } \\ \text { WL } & \text { waste loading }\end{array}$


WSRC-TR-2005-00153

Revision 0

\subsection{INTRODUCTION}

Crystallization (or devitrification) in nuclear waste glasses is an important consideration in terms of processing and product performance (i.e., durability of the final waste form) requirements. With respect to the impacts of crystallization on processing issues, the Defense Waste Processing Facility (DWPF) uses a liquidus temperature $\left(T_{L}\right)$ model (Brown et al. 2001) and an imposed $T_{L}$ limit for feed acceptability to avoid bulk devitrification within the melter. In terms of product quality or the durability of the waste form, the impacts of devitrification depend on the type and extent of crystallization.

For example, Jantzen and Bickford (1984) assessed the impact of spinel (nominally $\mathrm{NiFe}_{2} \mathrm{O}_{4}$ ), sodium iron silicate (acmite, $\left.\mathrm{NaFeSi}_{2} \mathrm{O}_{6}\right)$, and alkali silicate phases $\left(\mathrm{Li}_{2} \mathrm{SiO}_{3}\right.$ and $\mathrm{NaAlSiO}_{4}$ (nepheline)) on the durability of DWPF-type glasses as a function of heat treatment (quenched versus slow cooled). In that study, crystallization only occurred upon isothermal heat treatments (above $500^{\circ} \mathrm{C}$ ) or slow cooling - the quenched glasses were homogeneous (void of devitrification). The results indicated that the formation of spinel had little or no effect on the durability of Savannah River Laboratory (SRL) 165- or SRL 131-based glasses, while the formation of acmite produced a small but noticeable increase in the rate of dissolution of the matrix glass. The formation of $\mathrm{Li}_{2} \mathrm{SiO}_{3}$ and $\mathrm{NaAlSiO}_{4}$ (nepheline) only occurred in the SRL 131 glasses which resulted in a $2-3 \mathrm{X}$ decrease in the durability of the final glass product as compared to their quenched (non-crystallized) counterparts. ${ }^{1}$ Jantzen and Bickford (1984) indicated that the more complex devitrification (in terms of the number of phases formed) that was observed in the SRL 131-based glasses was primarily due to the higher alkali content relatively to the SRL 165-based glasses. Given these results, Jantzen and Bickford (1984) concluded that "the effects of devitrification on the durability of the SRL waste glasses demonstrate that devitrification has less of an effect than compositional changes." That is, the differences in durability observed between the SRL 165 and SRL 131 glasses due to their compositional differences were greater than the impacts of devitrification within a specific glass system. With respect to Sludge Batch 4 (SB4), of particular interest is the formation of acmite and nepheline in the higher alkali based SRL 131 glasses (especially when coupled with the high $\mathrm{Al}_{2} \mathrm{O}_{3}$ content of these glasses similar to that projected for SB4 - the application to SB4 is discussed in Section 2.0).

Cicero et al. (1993) also studied the impact of devitrification on durability of DWPF-type glasses. In that study, seven DWPF glass composition as projected by the DWPF Waste Form Compliance Plan (WCP) were fabricated, heat treated (using isothermal holds at various temperatures and times), and subjected to the PCT. ${ }^{2}$ The PCT response was then correlated with the type and extent (vol\%) of crystallization as determined by X-ray diffraction (XRD) analysis. Trevorite (spinel), acmite, lithium metasilicate, and nepheline crystals were found by XRD in all seven glass composition (in particular when heat treated between approximately 600 and $900^{\circ} \mathrm{C}$ ). The exception was the lack of lithium metasilicate in the Purex (high iron) glass. No detectable crystallization was found in the quenched (rapidly cooled) glasses. The XRD results were used to construct parabolic curves (i.e., vol\% crystallization versus time), sigmoidal fractional ingrowth

\footnotetext{
${ }^{1}$ Jantzen and Bickford (1984) measured durability using a 24-hour static leach test developed by Corning Glass Works and a 28-day static leach test which (at the time) was suggested by the Materials Characterization Center (MCC) - now referred to as MCC-1.

${ }^{2}$ Four of the seven compositions (referred to as Batch \#1 - \#4) were based on projection from existing high-level inventories while three were hypothetical compositions (referred to as Blend, high aluminum (HM), and Purex (high iron)). Samples were heat treated at $500,600,700,800,900,1000$, and $1100^{\circ} \mathrm{C}$ for times of $0.75,3,12,48,192$ or 768 hours. These times and temperatures are not expected during normal canister cooling or storage.
} 
curves, and ultimately time - temperature - transformation (TTT) diagrams for each of the seven glasses. The TTT diagrams provide a map of the type(s) of crystals expected as a function of time and temperature for each glass composition. Primary phase regions (based on a single crystal type or the co-existence of multiple crystal types) were defined for each glass. In addition, Cicero et al. (1993) superimposed the expected centerline cooling temperature profile onto the TTT diagrams for each glass. Based on a review of how this cooling profile cross-cuts the primary phase regions, the formation of Trevorite, acmite, and/or lithium metasilicate would be expected in all seven glasses. Based on the projected ccc schedule, the formation of nepheline would only be anticipated in the Purex (high iron) glass. Cicero et al. (1993) indicated that the TTT diagram for the Purex glass was different than all other glasses primarily based on the tendency to crystallize nepheline at lower temperatures. This tendency was correlated to the interaction between the glass and the alumina crucibles used and the increase in $\left(\mathrm{Li}_{2} \mathrm{O}+\mathrm{Na}_{2} \mathrm{O}\right)$ / $\left(\mathrm{SiO}_{2}+\mathrm{Al}_{2} \mathrm{O}_{3}\right)$ ratio compared to other compositions. With respect to the impact of crystallization on durability, the data suggested that the type and extent of devitrification ultimately determined the druabilty of the glass.

The impact of devitrification on durability of simulated nuclear waste glasses has also been evaluated by Kim et al. (1995). In that study, the durability response (as measured by the Product Consistency Test - PCT) (ASTM 2002) of over 120 simulated high level waste (HLW) glasses was assessed as a function of thermal heat treatment (quenched versus centerline canister cooled (сcc)). Again, the results of that study indicated that crystallization, depending on the type and extent (or fraction), can have an adverse effect on the chemical durability. More specifically, a strong increase in glass dissolution (or decrease in durability) was observed in glasses that formed aluminum-containing crystals, such as $\mathrm{NaAlSiO}_{4}$ and $\mathrm{LiAlSi}_{2} \mathrm{O}_{6}$, and crystalline $\mathrm{SiO}_{2}$ during the ccc treatment relative to their quenched counterparts (which were void of devitrification). Figure 1-1 compares the boron releases from quenched and ccc treated glasses as a function of volume fraction and type of crystalline phase formed. Based on the crystallinity of the ccc sample, glasses were classified into three groups: (1) glasses having no crystals, (2) glasses with total crystalline phase volume $<7$ vol\%, and (3) glasses with $\geq 7$ vol\% crystallization. Those glasses in which the effect of heat treatment resulted in no change to the PCT response lie along the $45^{\circ}$ line in Figure 1-1. If the slow cooling (ссс) had a negative impact on the durability response, the glass lies above the $45^{\circ}$ line (which passes through the origin) - the further above the line, the more severe the impact. Consider the set of glasses lying in the upper, left hand quadrant of Figure 1-1. X-ray diffraction results indicate that the formation of nepheline, $\mathrm{LiAlSi}_{2} \mathrm{O}_{6}$, and crystalline $\mathrm{SiO}_{2}$ (all above the 7 vol\% level as denoted by the closed circles) had a negative impact on the durability response as compared to their quenched (crystal-free) counterparts. 
WSRC-TR-2005-00153

Revision 0

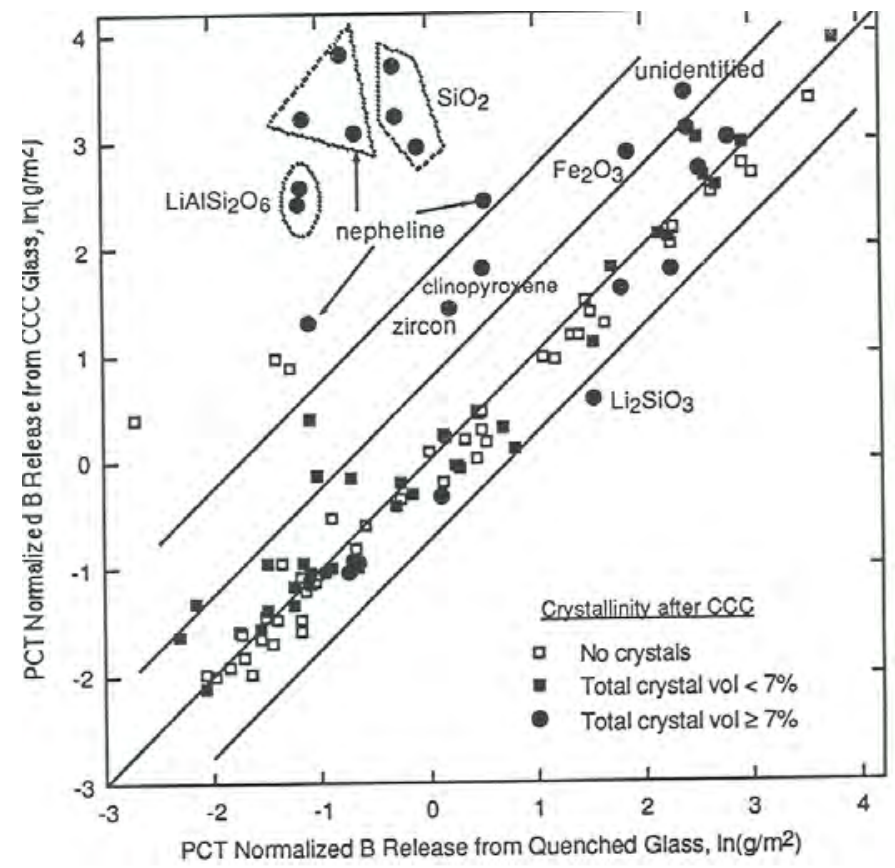

Figure 1-1. Normalized Boron Release $\left(\ln \left(g / \mathrm{m}^{2}\right)\right)$ from Quenched and ccc Treated Glasses.

The effect of crystallization on glass durability is complex and depends on several interrelated factors including the change in residual glass composition, the formation of internal stress or microcracks, and the preferential attack at the glass-crystal interface. Kim et al. (1995) also predicted the impact of both crystal type and extent on the durability of a glass by calculating the change to the residual glass composition followed by model based predictions. Figure 1-2 (from Kim et al. 1995) shows the predicted normalized boron release from a specific simulated HLW glass (CVS1-1) as a function of mass fraction of various primary crystalline phases. The formation of $\mathrm{NaAlSiO}_{4}, \mathrm{LiAlSi}_{2} \mathrm{O}_{6}$, and crystalline $\mathrm{SiO}_{2}$ is predicted to have a detrimental impact on durability which agrees quite well with the experimental data (see Figure 1-1) and those data reported by Jantzen and Bickford (1984). 
WSRC-TR-2005-00153

Revision 0

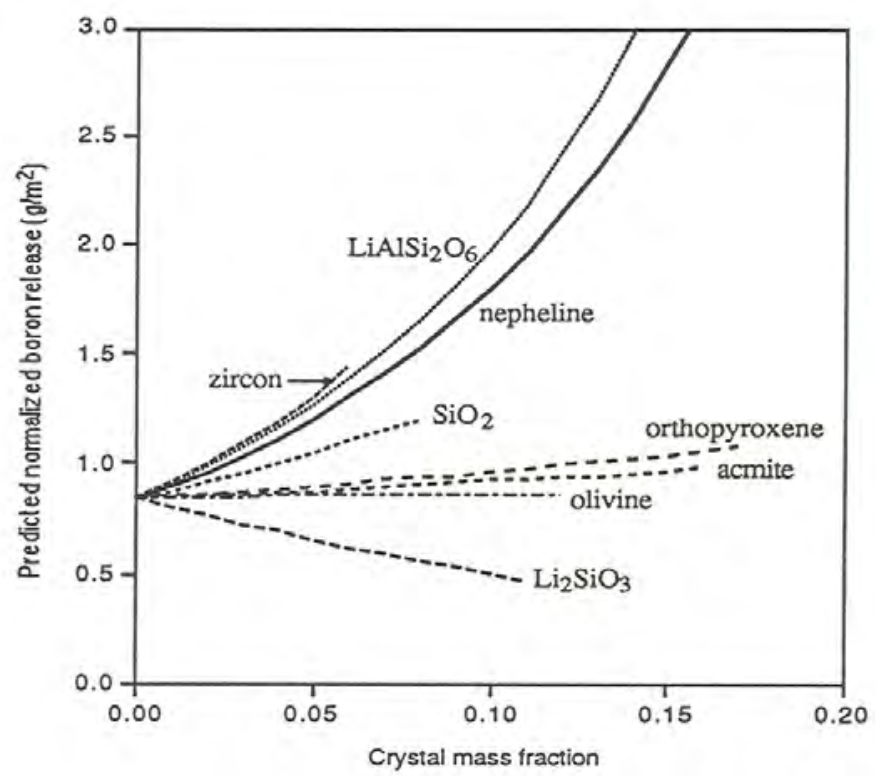

Figure 1-2. Predicted Normalized Boron Release from CVS1-1 Glass as a Function of Mass Fraction of Primary Crystalline Phases.

Although not summarized here, numerous studies (e.g., Bickford and Jantzen (1984), Jantzen et al. (1984), Bickford and Jantzen (1986), Spilman et al. (1986), Marra and Jantzen (1993), Li et al. (1997), and Riley et al. (2001)) have assessed the devitrification potential of HLW glass and its potential impact on durability. In general, these studies agree that the impact of devitrification on durability is dependent upon the type and extent of crystallization. However, there are some differences on the relative impacts (or magnitude) of the interrelated factors that ultimately determine the overall impact including the change in residual glass composition, the formation of internal stress or microcracks, and the preferential attack at the glass-crystal interface.

\subsection{APPLICABILITY TO THE SB4 SYSTEM}

The potential formation of nepheline and/or other aluminum/silicon-containing crystals is significant to the SB4 system due to the projected compositional views recently evaluated coupled with the frit development strategy. Compositional projections of SB4 by Lilliston (2005) indicate the sludge will be enriched in $\mathrm{Al}_{2} \mathrm{O}_{3}$ (relative to the $\mathrm{Al}_{2} \mathrm{O}_{3}$ concentration of previous sludge batches processed through the DWPF). Peeler and Edwards (2005a) have identified candidate frits (ranging in $\mathrm{Na}_{2} \mathrm{O}$ concentrations from 8 -13\%) for the SB4 compositional projections, which produce relatively large projected operating windows. This effort was based on the use of a "sliding $\mathrm{Na}_{2} \mathrm{O}$ scale" given the historical data linking the alkali content of the glass to melt rate. More specifically, previous research and DWPF processing have indicated that melt rate typically increases as the $\mathrm{Na}_{2} \mathrm{O}$ content of the glass increases. The use of the "sliding $\mathrm{Na}_{2} \mathrm{O}$ scale” concept was extremely effective in the development of Frit 418 for SB3 (Peeler and Edwards (2003)) and has been used to identify candidate frit compositions (relatively high in $\mathrm{Na}_{2} \mathrm{O}$ ) for SB4. However, the combination of a high $\mathrm{Al}_{2} \mathrm{O}_{3}$ sludge stream coupled with a desired high $\mathrm{Na}_{2} \mathrm{O}$ based glass (as a result of the use of a high $\mathrm{Na}_{2} \mathrm{O}$ frit and/or a less washed sludge) may result in the targeted glass compositions lying in the "phase field" prone to nepheline formation. 
Although it is well known that the addition of $\mathrm{Al}_{2} \mathrm{O}_{3}$ to borosilicate glasses enhances the durability of the waste form (through creation of network-forming tetrahedral $\mathrm{Na}^{+}-\left[\mathrm{AlO}_{4 / 2}\right]^{-}$pairs (Kim et al. (1995) and $\mathrm{Li}$ et al. (2003)), the combination of high $\mathrm{Al}_{2} \mathrm{O}_{3}$ and $\mathrm{Na}_{2} \mathrm{O}$ can lead to the formation of nepheline $\left(\mathrm{NaAlSiO}_{4}\right)$. Because nepheline removes three moles of glass forming oxides $\left(\mathrm{Al}_{2} \mathrm{O}_{3}\right.$ and $\left.2 \mathrm{SiO}_{2}\right)$ per each mole of $\mathrm{Na}_{2} \mathrm{O}$, nepheline formation can result in a severe deterioration of the chemical durability of the glass as previously described.

$\mathrm{Li}$ et al. (2003) indicate that compositional variation studies have shown that apart from $\mathrm{Al}_{2} \mathrm{O}_{3}$ and $\mathrm{Na}_{2} \mathrm{O}$, the glass components that significantly affect nepheline formation are $\mathrm{B}_{2} \mathrm{O}_{3}$ and $\mathrm{SiO}_{2}$. The results from those studies lead to the following conclusions:

(1) Sodium alumino-borosilicate glasses are prone to nepheline crystallization if their compositions projected on the $\mathrm{Na}_{2} \mathrm{O}-\mathrm{Al}_{2} \mathrm{O}_{3}-\mathrm{SiO}_{2}$ ternary fall within or close to the nepheline primary phase field. In particular, durable glasses with $\mathrm{SiO}_{2} /\left(\mathrm{SiO}_{2}+\mathrm{Na}_{2} \mathrm{O}+\right.$ $\left.\mathrm{Al}_{2} \mathrm{O}_{3}\right)>0.62$, where the chemical formula stand for the mass fractions in the glass, do not precipitate nepheline as their primary phase.

(2) Whereas $\mathrm{Al}_{2} \mathrm{O}_{3}$ and $\mathrm{Na}_{2} \mathrm{O}$ tend to enhance nepheline formation, an increased fraction of $\mathrm{B}_{2} \mathrm{O}_{3}$ tends to suppress its formation. ${ }^{3}$

(3) Nepheline crystallization kinetics is rapid with nearly a zero induction time.

The work performed by Jantzen and Bickford (1984) and Cicero et al. (1993) also found a positive correlation between the temperature of crystallization of alkali silicate phases (e.g., $\mathrm{Li}_{2} \mathrm{SiO}_{3}$ and $\left.\left.\mathrm{NaAlSiO}\right)_{4}\right)$ and the $\left(\mathrm{Li}_{2} \mathrm{O}+\mathrm{Na}_{2} \mathrm{O}\right) /\left(\mathrm{SiO}_{2}+\mathrm{Al}_{2} \mathrm{O}_{3}\right)$ ratio for DWPF-type glasses. To avoid potential formation of these phases, waste glasses are typically formulated outside the nepheline primary phase field given the rapid crystallization kinetics and potential impacts on durability. This can have a negative impact on waste loading as lower waste loadings may minimize the formation potential.

\subsection{AN ASSESSMENT OF NEPHELINE FORMATION POTENTIAL}

With respect to SB4, Lilliston (2005) provided nominal sludge compositions for twenty SB4 blending scenarios. Based on those projected compositions, Peeler and Edwards (2005a) assessed various frit compositions with respect to model-based, projected operating windows. The primary frits covered $\mathrm{Na}_{2} \mathrm{O}$ concentrations ranging from 8 wt\% (in Frit 418) to 13\% (in Frit 431). In addition to frit development efforts, Peeler and Edwards (2005b) also performed a preliminary assessment on the need to perform a variability study for SB4 using various SB4 compositional blending scenarios when coupled with the range of frit compositions. In that study, 48 glass compositions were identified that would provide the greatest challenge to the process property models in terms of model applicability (the primary objective of a variability study). The four specific blending scenarios used in that study were: (1) 1100 Can Baseline, (2) 1100 Can Max Al, Na; Min Mn, Ni, (3) 1100 Can Max Mg, and (4) 1100 Can Max Ni. Note, the "Max Ti" option as defined by Lilliston (2005) was not included given the $\mathrm{TiO}_{2}$ concentration is $\sim 0.03 \mathrm{wt} \%$ without the addition of the Actinide Removal Process (ARP) streams. Issues associated with $\mathrm{TiO}_{2}$ impacts to the operating windows and/or model applicability were addressed with the addition of ARP Appendix K (referred to as ARP K) to these 4 sludge options (Peeler and Edwards 2005c).

\footnotetext{
${ }^{3}$ In terms of frit development efforts for SB4, Stone and Joseph (2001) have shown that increased concentrations of $\mathrm{B}_{2} \mathrm{O}_{3}$ tend to reduce melt rate. Therefore, if nepheline formation is a concern in the SB4 system, alternative frit compositions with increased concentrations of $\mathrm{B}_{2} \mathrm{O}_{3}$ may be used but perhaps at the expense of melt rate.
} 
Each of the sludge compositions was combined with Frit 320 and with Frit 418 at waste loadings (WLs) of 30\%, 35\%, and $40 \%{ }^{4}$ This led to 48 glass compositions, which are provided in Table 3-1 and Table 3-2. These tables of glass compositions provide a sampling of the glass systems that have been investigated as part of the paper studies supporting the SB4 frit development efforts (Peeler and Edwards 2005a, 2005b, and 2005c). In addition to supporting the assessment of the need for a variability study, the glasses also provided a technical basis for evaluating the potential formation of nepheline for projected SB4 blending scenarios. The use of the 1100 Baseline option provides a central comparison point as this option currently serves as the baseline flowsheet for SB4. The use of these different flowsheets also provides compositional variation from which the formation of nepheline can be evaluated. For example, the $1100 \mathrm{Can} \mathrm{Max} \mathrm{Al}, \mathrm{Na}$ case will be an interesting option as this case increases both $\mathrm{Al}_{2} \mathrm{O}_{3}$ and $\mathrm{Na}_{2} \mathrm{O}$ concentrations in glass as waste loadings are increased. In addition, knowing that the primary source of $\mathrm{SiO}_{2}$ stems from the frit, as WLs increase the $\mathrm{SiO}_{2}$ content of the glass decreases - again increasing the probability of nepheline formation according to the discriminator developed by Li et al. (2003). Based on that theory, the probability of nepheline formation should increase as high-alkali frits are used and should further increase with higher WLs for SB4.

\footnotetext{
${ }^{4}$ Eight sludge compositions resulting from the four 1100 Canister baseline options with and without ARP Appendix K combined with 2 frit compositions (Frit 320 and Frit 418) at three different WLs (30, 35, and 40\%) provided 48 glass compositions.
} 
Table 3-1. Compositions of Select Glasses from the SB4 Glass Systems (Part 1: $\mathrm{Al}_{2} \mathrm{O}_{3}$ through MnO)

\begin{tabular}{|c|c|c|c|c|c|c|c|c|c|c|c|c|c|c|c|c|}
\hline $\begin{array}{l}\mathrm{WL} \\
(\%) \\
\end{array}$ & \begin{tabular}{|c|} 
Frit \\
ID \\
\end{tabular} & Sludge Option & $\begin{array}{c}\mathrm{Al}_{2} \mathrm{O} \\
3 \\
\end{array}$ & $\mathrm{~B}_{2} \mathrm{O}_{3}$ & $\mathrm{BaO}$ & $\mathrm{CaO}$ & $\begin{array}{c}\mathrm{Ce}_{2} \mathrm{O} \\
3 \\
\end{array}$ & $\begin{array}{c}\mathrm{Cr}_{2} \mathrm{O} \\
3 \\
\end{array}$ & $\begin{array}{c}\mathrm{Cs} 2 \\
\mathrm{O} \\
\end{array}$ & $\mathrm{CuO}$ & $\begin{array}{c}\mathrm{Fe}_{2} \mathrm{O} \\
3 \\
\end{array}$ & $\mathrm{~K}_{2} \mathrm{O}$ & $\begin{array}{c}\mathrm{La}_{2} \mathrm{O} \\
3 \\
\end{array}$ & $\mathrm{Li}_{2} \mathrm{O}$ & $\mathrm{MgO}$ & $\mathrm{MnO}$ \\
\hline 30 & 32 & 110 Can Base & 680 & 560 & 05 & 067 & (1) & $\begin{array}{ll}08 \\
08\end{array}$ & مهم & 003 & 780 & 031 & 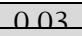 & 5 & 75 & 175 \\
\hline 35 & 32 & 1100 Can Baseline & 794 & 520 & 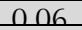 & 078 & مO7 & مח & مهم & 003 & 910 & 036 & 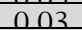 & 520 & 068 & 204 \\
\hline 40 & 32 & 1100 ran Baseline & 907 & 480 & م06 & 089 & م08 & 010 & (م⿳⺈冂大 & 003 & 104 & 041 & $\mathrm{O} 04$ & 480 & 078 & 234 \\
\hline 30 & 41 & 1100 Can Baseline & 680 & 560 & 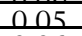 & 067 & م06 & م08 & (مחم & 0303 & 780 & 031 & 003 & 560 & 058 & 175 \\
\hline 35 & 41 & 1100 Can Baseline & 794 & 520 & مी & 078 & 崩 & (1) & (1) & 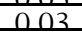 & 910 & 036 & 崩3 & 520 & 068 & 204 \\
\hline 40 & 41 & 1100 Can Baseline & 907 & 480 & $\frac{\sqrt{06}}{006}$ & $\frac{10}{089}$ & $\frac{\sqrt{18}}{008}$ & $\frac{\sqrt{10}}{010}$ & 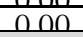 & $\frac{\sqrt{12}}{003}$ & 104 & $\frac{\sqrt{3 b}}{041}$ & $\frac{\sqrt{04}}{004}$ & 480 & $\frac{\sqrt{20}}{078}$ & $\frac{244}{234}$ \\
\hline 30 & 32 & 1100 Can Max $\Delta 1$ Na $\cdot$ Min $\mathrm{Mn}$ Ni_ I & 946 & 560 & 003 & 066 & 0 مी & 007 & مחم & 002 & 682 & 051 & 003 & 560 & 055 & 143 \\
\hline 35 & 32 & 1100 Can Max Al Na. Min Mn Ni II & 110 & 520 & 04 & 077 & م07 & 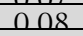 & 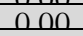 & 003 & 795 & 060 & 003 & 520 & 064 & 167 \\
\hline 40 & 32 & 1100 Can Max Al Na $\cdot$ Min Mn Ni II & 126 & 480 & $\mathrm{O} 04$ & $\frac{188}{088}$ & 08 & 09 & مחم0 & $\frac{\mathrm{U}}{0.3}$ & 909 & 068 & 003 & 480 & $\frac{124}{073}$ & 191 \\
\hline 30 & 41 & 1100 Can Max $A 1$ Na. Min $\mathrm{Mn}$ Ni U U & 946 & 560 & 003 & 066 & 0 م & 007 & مهم⿻ & 002 & 6.82 & 051 & 003 & 560 & 055 & 143 \\
\hline 35 & 41 & $110 \mathrm{ON}$ Can Max $\mathrm{Al} \mathrm{Na} \cdot \mathrm{Min} \mathrm{Mn} \mathrm{Ni}$ & 110 & 520 & 04 & 077 & م07 & م08 & مهم & 003 & 795 & 060 & 003 & 520 & 064 & 167 \\
\hline 30 & 32 & $\frac{\mathrm{C}}{1100 \text { Can Max Mo }}$ & 650 & 560 & $\frac{\sqrt{04}}{0.5}$ & $\frac{10}{068}$ & $\frac{\omega}{006}$ & $\frac{\mathrm{U}}{0 \times 7}$ & 药 & $\frac{\sqrt{2}}{022}$ & 796 & 027 & $\frac{\mathrm{U}}{003}$ & 560 & 064 & 183 \\
\hline$\frac{31}{35}$ & 32 & 1100 Can Max Mo & $\frac{6210}{758}$ & 520 & $\frac{\omega}{006}$ & $\frac{\sqrt{68}}{079}$ & $\frac{\sqrt{6}}{007}$ & $\frac{\sqrt{10}}{0 \times 9}$ & 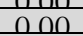 & $\frac{\sqrt{12}}{003}$ & 929 & 032 & $\frac{\sqrt{13}}{003}$ & $\frac{200}{520}$ & $\frac{\sqrt{64}}{075}$ & $\frac{129}{214}$ \\
\hline 40 & 32 & 1100 Can Max Mo & 866 & 480 & (1) & 091 & (1) & $\frac{10}{010}$ & 定 & 003 & 106 & 036 & $\mathrm{O} 04$ & 480 & 086 & 244 \\
\hline 30 & 41 & 110 & 650 & 560 & $\frac{\omega}{0.5}$ & 068 & 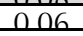 & 崩 & 宸 & $\frac{1}{0.22}$ & 796 & 027 & $\frac{\mathrm{U}}{\mathrm{O} 03}$ & 560 & 064 & 183 \\
\hline 35 & 41 & 1100 Can Max Mo & 758 & 520 & م & 079 & 07 & 0 & مهم & 003 & 929 & 032 & 003 & 520 & 075 & 214 \\
\hline 40 & 41 & 110 Can Max Mo & 866 & 480 & (106 & 091 & (1) & (10 & 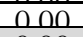 & (103 & 106 & 036 & م04 & 480 & 086 & 244 \\
\hline 30 & 32 & 1100 Can Max Ni & 673 & 560 & م & 057 & مी & 08 & مهم & 003 & 726 & 034 & 003 & 560 & 035 & 180 \\
\hline 35 & 32 & 1100 Can Max Ni & 785 & 520 & $\frac{\mathrm{U}}{0.7}$ & $\frac{110}{066}$ & $\frac{\mathrm{U}}{007}$ & $\frac{10}{010}$ & 崩 & $\frac{\mathrm{U}}{003}$ & 847 & 040 & $\frac{\sqrt{03}}{003}$ & 520 & 040 & 210 \\
\hline 40 & $\frac{31}{32}$ & 1100 Can Max Ni & 897 & 480 & $\frac{\sqrt{18}}{0 \times 8}$ & $\frac{\omega}{076}$ & $\frac{\sqrt{11}}{008}$ & $\frac{11}{011}$ & 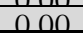 & $\frac{\sqrt{13}}{003}$ & 968 & $\frac{\sqrt{410}}{045}$ & $\frac{\sqrt{12}}{003}$ & 480 & $\frac{146}{046}$ & 240 \\
\hline 30 & 41 & & 673 & 560 & م06 & $\frac{10}{0.57}$ & $\frac{\omega}{006}$ & $\frac{11}{0.8}$ & 崩 & $\frac{\sqrt{103}}{003}$ & 726 & 034 & $\frac{\sqrt{12}}{003}$ & 560 & $\frac{146}{035}$ & 180 \\
\hline 35 & 41 & 11 & 785 & 520 & م07 & 0 & 崩 & 岂 10 & 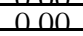 & م03 & 847 & 040 & 崩 & 520 & 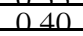 & 210 \\
\hline 40 & 41 & $110 \mathrm{Ca}$ & 897 & 480 & $\frac{\sqrt{3}}{0 \times 8}$ & $\frac{\mathrm{U}}{076}$ & $\frac{\sqrt{13}}{0}$ & $\frac{111}{011}$ & - & $\frac{\sqrt{03}}{003}$ & 968 & 045 & $\frac{\sqrt{03}}{003}$ & 480 & 046 & 240 \\
\hline 30 & 32 & SB4 110م Can Raseline - Ann K K & 635 & 560 & 005 & 064 & 0 & 007 & مחمת & 002 & 742 & 028 & 003 & 560 & 053 & 172 \\
\hline$\frac{411}{30}$ & 41 & SB4 1100 Can Baseline - Ann K K & 635 & 560 & مـ & $\frac{\sqrt{04}}{064}$ & بـ & لمـ & 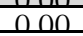 & س & 742 & $\frac{\sqrt{28}}{028}$ & $\frac{\sqrt{14}}{003}$ & $\frac{4}{560}$ & $\frac{\sqrt{1}}{053}$ & 172 \\
\hline$\frac{30}{35}$ & $\frac{41}{41}$ & SB4 1100 Can Raseline - Ann K K & $\frac{634}{741}$ & $\frac{2011}{520}$ & $\frac{\sqrt{0}}{0.5}$ & $\frac{\sqrt{64}}{074}$ & $\frac{\sqrt{6}}{007}$ & عـ & - & $\frac{\sqrt{12}}{0.3}$ & 866 & $\frac{\sqrt{2} 8}{033}$ & $\frac{\sqrt{13}}{0.3}$ & $\frac{200}{520}$ & $\frac{\sqrt{13}}{062}$ & $\frac{1120}{200}$ \\
\hline 40 & 41 & SB4 1100 Can & 847 & 480 & م06 & 085 & مी & م- & 狊 & 003 & 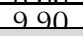 & 038 & مـ & 480 & 071 & 229 \\
\hline 30 & 32 & SB4 1100 Can Max Al Na. Min Mn Ni & 876 & 560 & 003 & 063 & 006 & 007 & 管 & 002 & 653 & 047 & 003 & 560 & 050 & 143 \\
\hline$\frac{30}{35}$ & 32 & SB4 1100 Can Max Al Na. Min Mn Ni & $\frac{80}{102}$ & 520 & $\frac{\sqrt{3}}{0.4}$ & $\frac{\sqrt{63}}{073}$ & $\frac{\sqrt{6}}{0.7}$ & $\frac{\sqrt{1}}{0 \Omega 8}$ & 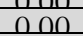 & $\frac{\sqrt{2}}{002}$ & $\frac{6,3}{761}$ & $\frac{\sqrt{41}}{055}$ & $\frac{\sqrt{13}}{003}$ & $\frac{220}{520}$ & $\frac{\sqrt{10}}{059}$ & $\frac{14}{167}$ \\
\hline 40 & 32 & SB4 1100 Can Max Al Na. Min Mn Ni & 116 & 480 & 0.4 & 084 & 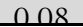 & 009 & مهم: & 003 & 870 & 062 & 003 & 480 & 067 & 191 \\
\hline 30 & 41 & SB4 1100 Can Max Al Na. Min Mn Ni & 876 & 560 & 003 & مــ & 0 & 007 & مחم & 002 & 653 & 047 & 0 & 560 & 050 & 143 \\
\hline 35 & 41 & SB4 1100 Can Max $41 \mathrm{Na} \cdot \mathrm{Min} \mathrm{Mn}$ Ni & 102 & 520 & ת & 073 & لمب & لمب & 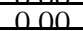 & 002 & 761 & 055 & 0 & 520 & 059 & 167 \\
\hline$\frac{30}{40}$ & $\frac{41}{41}$ & SB4 1100 Can Max Al Na. Min Mn Ni & 116 & $\frac{210}{480}$ & مـ & $\frac{13}{084}$ & لمهـ & $\frac{\sqrt{0}}{009}$ & - & $\frac{\sqrt{12}}{003}$ & $\frac{161}{870}$ & $\frac{\sqrt{2}}{062}$ & $\frac{\omega}{0}$ & $\frac{30}{480}$ & $\frac{\sqrt{39}}{067}$ & $\frac{161}{191}$ \\
\hline 30 & 32 & SB4 1100 Can Max Mo - Ann K K & 607 & 560 & 05 & 0.64 & مी & 07 & مח & 002 & 757 & 025 & & 560 & 059 & 179 \\
\hline$\frac{31}{35}$ & 32 & $M \sigma-\Delta n n K$ & 709 & 520 & $\frac{\mathrm{U}}{0.5}$ & $\frac{\mathrm{U}}{075}$ & $\frac{\mathrm{U}}{007}$ & $\frac{\sqrt{0}}{0}$ & 药 & $\frac{\mathrm{U}}{03}$ & 883 & 029 & 荝 & 520 & 069 & $\frac{209}{209}$ \\
\hline 40 & 32 & Max Mr - Ann K & 810 & 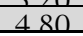 & عم & $\frac{18}{0}$ & بـ & $\frac{1}{0}$ & 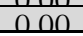 & U & 10 & $\frac{\pi}{0}$ & $\frac{1}{0}$ & 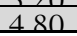 & $\frac{\sqrt{20}}{078}$ & 239 \\
\hline 30 & 41 & SB4 1100 Can Max Mo - An & 60 & 56 & مان & م & 0 & مي & 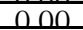 & 002 & 75 & 025 & (1) & 560 & 059 & 179 \\
\hline 35 & 41 & SB4 1100 Can Max Mo - Ann K & 709 & 520 & 05 & 075 & ـ & مان & ممOم & 003 & 883 & 029 & مان & 520 & 069 & 209 \\
\hline 40 & 41 & SB4 1100 Can Max Mo - Ann K & 810 & 480 & م & 086 & ( & 009 & 管 & 003 & 100 & 033 & 004 & 480 & 078 & 239 \\
\hline$\frac{411}{30}$ & $\frac{41}{32}$ & SB4 1100 Can Max Ni - Ann K & $\frac{801}{628}$ & $\frac{480}{560}$ & مـم & $\frac{\sqrt{06}}{054}$ & لمه & $\frac{\sqrt{4}}{008}$ & 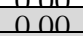 & $\frac{\sqrt{3}}{002}$ & $\frac{\sqrt{6}}{693}$ & $\frac{\sqrt{3 i}}{031}$ & $\frac{\sqrt{4}}{0.3}$ & $\frac{480}{560}$ & $\frac{\sqrt{8}}{032}$ & 176 \\
\hline 35 & 32 & $-\Delta \ln K$ & 733 & 520 & م07 & 0.63 & م & م09 & 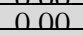 & 003 & 809 & 03 & م & 520 & 037 & 206 \\
\hline 40 & 32 & SB4 110 & 837 & 480 & م岗8 & 072 & 荝 & 0 & م & م & 9 & 04 & 0 & 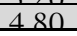 & 042 & \\
\hline$\frac{40}{30}$ & 41 & $-\Delta r$ & 6 & 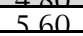 & & م & & & & & & $\mathrm{C}$ & & & & \\
\hline 35 & 41 & SB4 1100 Can Max $\mathrm{Ni}-\mathrm{Ann} \mathrm{K}$ & 733 & 520 & م07 & 063 & 07 & م09 & 每 & 003 & 809 & 036 & 003 & 520 & 037 & 20 \\
\hline 40 & 41 & SB4 1100 Can Max Ni - Ann K & 837 & 480 & 0 & 072 & 008 & 010 & 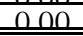 & 003 & 924 & 042 & 003 & 480 & 042 & 235 \\
\hline
\end{tabular}


Table 3-2. Compositions of Select Glasses from the SB4 Glass Systems (Part 2: $\mathrm{Na}_{2} \mathrm{O}$ through $\mathrm{ZrO}_{2}$ and Property Predictions)

\begin{tabular}{|c|c|c|c|c|c|c|c|c|c|c|c|c|c|c|c|c|}
\hline $\begin{array}{l}\mathrm{WL} \\
(\%)\end{array}$ & $\begin{array}{c}\text { Frit } \\
\text { ID }\end{array}$ & Sludge Option & $\mathrm{Na}_{2} \mathrm{O}$ & $\mathrm{NiO}$ & $\mathrm{PbO}$ & $\mathrm{SO}_{4}$ & $\mathrm{SiO}_{2}$ & $\mathrm{ThO}_{2}$ & $\mathrm{TiO}_{2}$ & $\mathrm{U}_{3} \mathrm{O}_{8}$ & $\mathrm{ZnO}$ & $\mathrm{ZrO}_{2}$ & alkalis & $\begin{array}{c}\text { Viscosity } \\
\text { (Poise) }\end{array}$ & Del Gp & $\mathrm{T}_{\mathrm{L}}\left({ }^{\circ} \mathrm{C}\right)$ \\
\hline 30 & 320 & 1100 Can Baseline & 15.01 & 1.11 & 0.05 & 0.33 & 51.22 & 0.01 & 0.01 & 2.78 & 0.04 & 0.08 & 20.9 & 43.7 & 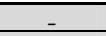 & 816.9 \\
\hline 35 & 320 & 1100 Can Baseline & 15.51 & 1.30 & 0.06 & 0.38 & 47.76 & 0.01 & 0.01 & 3.25 & 0.04 & 0.10 & 21.1 & 36.5 & - & 884.2 \\
\hline 40 & 320 & 1100 Can Baseline & 16.01 & 1.49 & 0.07 & 0.44 & 44.29 & 0.01 & 0.01 & 3.71 & 0.05 & 0.11 & 21.2 & 29.7 & - & 945.1 \\
\hline 30 & 418 & 1100 Can Baseline & 1221 & 1.11 & 0.05 & 0.33 & 54.02 & 0.01 & 01 & 278 & 004 & م08 & 18.1 & 75.8 & & 8627 \\
\hline 35 & 418 & 1100 Can Baseline & 12.91 & 1.30 & 0.06 & 0.38 & 50.36 & 0.01 & 0.01 & 3.25 & 0.04 & 0.10 & 18.5 & 63.8 & - & 928.3 \\
\hline 40 & 418 & 1100 Can Baseline & 1361 & 1.49 & (207 & 0.44 & 4669 & 001 & 001 & 3.71 & (205 & 0.11 & 18.8 & 522 & & 9866 \\
\hline 30 & 320 & 1100 Can Max Al. Na: Min Mn. Ni. U & 15.26 & 0.44 & 0.06 & 0.33 & 51.36 & 0.01 & 0.01 & 1.58 & 0.03 & 0.07 & 21.4 & 54.7 & - & 780.5 \\
\hline 35 & 320 & 1100 Can MaxAl. Na: Min Mn. Ni. U & 15.80 & 0.51 & 0.07 & 0.39 & 47.92 & 0.02 & 0.01 & 1.85 & 0.04 & 0.08 & 21.6 & 48.4 & 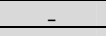 & 837.2 \\
\hline 40 & 320 & 1100 Can Max Al. Na: Min Mn. Ni. U & 16.35 & 0.58 & 0.08 & 0.44 & 44.48 & 0.02 & 0.01 & 2.11 & 0.04 & 0.10 & 21.8 & 42.0 & & 887.0 \\
\hline 30 & 418 & 1100 Can Max Al. Na: Min Mn. Ni. U & 12.46 & 0.44 & 0.06 & 0.33 & 54.16 & 0.01 & 0.01 & 1.58 & 0.03 & 0.07 & 18.6 & 93.6 & -9.450 & 818.1 \\
\hline 35 & 418 & 1100 Can Max Al. Na: Min Mn. Ni. U & 13.20 & 0.51 & 0.07 & 0.39 & 50.52 & 0.02 & 0.01 & 1.85 & 0.04 & 0.08 & 19.0 & 83.2 & -9.464 & 872.3 \\
\hline 40 & 418 & 1100 Can Max Al. Na: Min Mn. Ni. U & 13.95 & 0.58 & 0.08 & 0.44 & 46.88 & 0.02 & 0.01 & 2.11 & 0.04 & 0.10 & 19.4 & 72.5 & -9.478 & 919.1 \\
\hline 30 & 320 & 1100 Can Max Mg & 14.99 & 1.14 & 0.05 & 0.33 & 5123 & 0.01 & 0.01 & 2.81 & 0.04 & 0.08 & 20.9 & 42.5 & & 817.8 \\
\hline 35 & 320 & 1100 Can Max Mg & 15.49 & 1.32 & 0.05 & 0.38 & 47.76 & 0.01 & 0.01 & 3.28 & 0.04 & 0.09 & 21.0 & 35.3 & 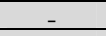 & 885.9 \\
\hline 40 & 320 & 1100 Can Max Mg & 15.99 & 1.51 & 0.06 & 0.44 & 44.30 & 0.01 & 0.01 & 3.75 & 0.05 & 0.11 & 21.1 & 28.5 & - & 947.7 \\
\hline 30 & 418 & 1100 Can Max Mg & 12.19 & 1.14 & 0.05 & 0.33 & 54.03 & 0.01 & 0.01 & 2.81 & 0.04 & 0.08 & 18.1 & 73.8 & 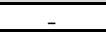 & 864.3 \\
\hline 35 & 418 & 1100 Can Max Mg & 12.89 & 1.32 & 0.05 & 0.38 & 50.36 & 0.01 & 0.01 & 3.28 & 0.04 & 0.09 & 18.4 & 61.8 & 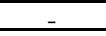 & 930.8 \\
\hline 40 & 418 & 1100 Can Max Mo & 13.59 & 1.51 & 0.06 & 0.44 & 4670 & 001 & 001 & 3.75 & 005 & 0.11 & 18.7 & 502 & & 9901 \\
\hline 30 & 320 & 1100 Can Max Ni & 14.86 & 1.82 & 0.05 & 0.33 & 51.09 & 0.01 & 0.00 & 3.22 & 0.04 & 0.09 & 20.8 & 45.0 & - & 856.5 \\
\hline 35 & 320 & 1100 Can Max Ni & 15.34 & 2.12 & 0.06 & 0.38 & 4760 & 001 & 001 & 375 & 05 & 0.11 & 20.9 & 37.8 & 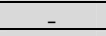 & 9302 \\
\hline 40 & 320 & 1100 Can Max Ni & 15.82 & 2.43 & 0.06 & 0.44 & 44.11 & 0.01 & 0.01 & 4.29 & 0.05 & 0.12 & 21.1 & 31.0 & - & 997.3 \\
\hline 30 & 418 & 1100 Can Max Ni & 12.06 & 1.82 & 0.05 & 0.33 & 53.89 & 0.01 & 0.00 & 3.22 & 0.04 & 0.09 & 18.0 & 78.0 & - & 906.5 \\
\hline 35 & 418 & 1100 Can Max Ni & 12.74 & 2.12 & 0.06 & 0.38 & 50.20 & 0.01 & 0.01 & 3.75 & 0.05 & 0.11 & 18.3 & 66.1 & - & 978.7 \\
\hline 40 & 418 & 1100 Can Max Ni & 13.42 & 2.43 & 0.06 & 0.44 & 46.51 & 0.01 & 0.01 & 4.29 & 0.05 & 0.12 & 18.7 & 54.5 & & 1043.4 \\
\hline 30 & 320 & SB4 1100 Can Baseline - Ann K K & 15.51 & 105 & 0.05 & 0.38 & 51.16 & 001 & 073 & 262 & 004 & 008 & 21.4 & 40.1 & - & 7932 \\
\hline 35 & 320 & SB4 1100 Can Baseline - Ann. K & 16.10 & 1.22 & 0.06 & 0.44 & 47.69 & 0.01 & 0.86 & 3.05 & 0.04 & 0.10 & 21.6 & 32.8 & - & 856.7 \\
\hline 40 & 320 & SB4 1100 Can Baseline - Ann . K & 1668 & 1.40 & 0.06 & 0.51 & 4422 & 0.01 & 0.98 & 3.49 & 0.05 & 0.11 & 21.9 & 260 & 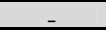 & 9137 \\
\hline 30 & 418 & SB4 1100 Can Baseline - Ann. K & 12.71 & 1.05 & 0.05 & 0.38 & 53.96 & 0.01 & 0.73 & 2.62 & 0.04 & 0.08 & 18.6 & 69.8 & - & 836.9 \\
\hline 35 & 418 & SB4 1100 Can Baseline - Ann. K & 13.50 & 1.22 & 0.06 & 0.44 & 50.29 & 0.01 & 0.86 & 3.05 & 0.04 & 0.10 & 19.0 & 57.6 & - & 898.4 \\
\hline 40 & 418 & SB4 1100 Can Baseline - Ann. K & 14.28 & 1.40 & 0.06 & 0.51 & 46.62 & 0.01 & 0.98 & 3.49 & 0.05 & 0.11 & 19.5 & 46.1 & - & 952.9 \\
\hline 30 & 320 & SB4 1100 Can Max Al. Na: Min Mn. Ni. U & 15.74 & 0.43 & 0.06 & 0.38 & 51.29 & 0.01 & 0.73 & 1.53 & 0.03 & 0.07 & 21.8 & 49.2 & - & 764.1 \\
\hline 35 & 320 & SB4 1100 Can Max Al. Na: Min Mn. Ni. U & 16.36 & 0.51 & 0.07 & 0.44 & 47.84 & 0.02 & 0.86 & 1.78 & 0.03 & 0.08 & 22.1 & 42.4 & - & 818.9 \\
\hline 40 & 320 & SB4 1100 Can Max Al. Na: Min Mn. Ni. U & 16.99 & 0.58 & 0.08 & 0.51 & 44.39 & 0.02 & 0.98 & 2.04 & 0.04 & 0.09 & 22.4 & 35.7 & - & 867.0 \\
\hline 30 & 418 & SB4 1100 Can Max Al Na: Min Mn Ni U U & 1294 & 0.43 & 006 & 0.38 & 5409 & 001 & 073 & 1.53 & 003 & 007 & 190 & 847 & -9946 & 8008 \\
\hline 35 & 418 & SB4 1100 Can Max Al. Na: Min Mn. Ni. U & 13.76 & 0.51 & 0.07 & 0.44 & 50.44 & 0.02 & 0.86 & 1.78 & 0.03 & 0.08 & 19.5 & 73.4 & - & 853.1 \\
\hline 40 & 418 & SB4 1100 Can Max Al_ Na: Min Mn Ni. U & 14.59 & 0.58 & 008 & 0.51 & 4679 & 002 & 098 & 204 & 004 & 009 & 200 & 621 & 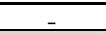 & 898.4 \\
\hline 30 & 320 & SB4 1100 Can Max Mo - Ann. K & 15.49 & 1.07 & 0.05 & 0.38 & 51.17 & 0.01 & 0.73 & 2.65 & 0.04 & 0.08 & 21.3 & 39.1 & - & 793.6 \\
\hline 35 & 320 & SB4 1100 Can Max Mo - Anp. K & 16.08 & 1.25 & 0.05 & 0.44 & 47.70 & 0.01 & 0.86 & 3.09 & 0.04 & 0.09 & 216 & 31.8 & - & 8577 \\
\hline 40 & 320 & SB4 1100 Can Max Mg - Ann K K & 1666 & 1.43 & 006 & 0.51 & 4422 & 001 & 0.98 & 3.53 & 005 & 0.10 & 218 & 250 & - & 9154 \\
\hline 30 & 418 & SB4 1100 Can Max Mo - Ann. K & 12.69 & 1.07 & 0.05 & 0.38 & 53.97 & 0.01 & 0.73 & 2.65 & 0.04 & 0.08 & 18.5 & 68.2 & - & 837.9 \\
\hline 35 & 418 & SB4 1100 Can Max Mo - Ann. K & 13.48 & 125 & 0.05 & 044 & 50.30 & 001 & 0.86 & 3.09 & 004 & 009 & 190 & 55.9 & & 900.1 \\
\hline 40 & 418 & SB4 1100 Can Max Mg - Ann. K & 14.26 & 1.43 & 0.06 & 0.51 & 46.62 & 0.01 & 0.98 & 3.53 & 0.05 & 0.10 & 19.4 & 44.4 & - & 955.3 \\
\hline 30 & 320 & SB4 1100 Can Max Ni - AnD. K & 15.38 & 1.69 & 0.05 & 0.38 & 51.04 & 0.01 & 0.73 & 3.01 & 0.04 & 0.09 & 21.3 & 41.1 & - & 827.7 \\
\hline 35 & 320 & SB4 1100 Can Max Ni - Ann. K & 15.94 & 1.97 & 0.05 & 0.44 & 47.55 & 0.01 & 0.85 & 3.51 & 0.04 & 0.10 & 21.5 & 33.8 & - & 896.5 \\
\hline 40 & 320 & $\mathrm{Max} \mathrm{Ni}-\mathrm{Ann} \cdot \mathrm{K}$ & 16.50 & 2.25 & 0.06 & 0.50 & 44.05 & 0.01 & 0.97 & 4.01 & 0.05 & 0.12 & 21.7 & 27.0 & 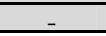 & 958.8 \\
\hline 30 & 418 & SB4 1100 Can Max Ni - Ann. K & 12.58 & 1.69 & 0.05 & 0.38 & 53.84 & 0.01 & 0.73 & 3.01 & 0.04 & 0.09 & 18.5 & 71.7 & - & 875.0 \\
\hline 35 & 418 & SB4 1100 Can Max Ni - AnD. K & 13.34 & 1.97 & 0.05 & 0.44 & 50.15 & 0.01 & 0.85 & 3.51 & 0.04 & 0.10 & 18.9 & 59.5 & 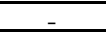 & 9420 \\
\hline 40 & 418 & SB4 1100 Can Max Ni - Ann. K & 14.10 & 2.25 & 0.06 & 0.50 & 46.45 & 0.01 & 0.97 & 4.01 & 0.05 & 0.12 & 19.3 & 47.9 & - & 1001.8 \\
\hline
\end{tabular}


WSRC-TR-2005-00153

Revision 0

\subsection{THE GLASS SELECTION PROCESS}

The 48 compositions were screened using the nepheline discriminator (i.e., $\mathrm{SiO}_{2} /\left(\mathrm{SiO}_{2}+\mathrm{Na}_{2} \mathrm{O}+\right.$ $\left.\mathrm{Al}_{2} \mathrm{O}_{3}\right)>0.62$ ) developed by Li et al. (2003). Table 4-1 summarizes the predicted nepheline ratio for each of the 48 glass compositions identified by Peeler and Edwards (2005b).

Although Li et al. (2003) define the "line of demarcation" between glasses that are prone to nepheline formation from those that are not based on a value of 0.62 , that line may be somewhat ill-defined. Therefore, to provide a higher probability of observing the formation of nepheline and the potential negative impact on durability, a value of 0.65 will be used to establish the glasses to be tested in this study. Using the "less conservative" value will not only increase the probability of forming nepheline but will also allow the assessment of several different blending scenarios, both frits (Frit 320 and Frit 418), and different WLs which will provide valuable insight into the frit selection process for SB4. More specifically, blending strategies, frit compositions, and WLs that avoid nepheline formation could be used to guide the frit selection process or to make compositional adjustments to the frit.

Given the use of the 0.65 discriminator value, there are twelve glasses from Table 4- 1 (see shaded cells) that fall into the category of being prone to the formation of nepheline. The nominal compositions of these glasses (referred to as Neph-01 through Neph-12) are listed in Table 4-2 and are primarily based on the use of Frit 320 and WLs targeting 40\%. In fact, 10 out of the 12 are Frit 320 based, and 8 of these 10 target a 40\% WL - independent of the SB4 blending scenario used. This is not unexpected due to the higher alkali content of Frit $320\left(12 \% \mathrm{Na}_{2} \mathrm{O}\right)$ relative to Frit $418\left(8 \% \mathrm{Na}_{2} \mathrm{O}\right)$ and the fact that as WLs increase, the $\mathrm{Na}_{2} \mathrm{O}$ concentrations increase and the $\mathrm{SiO}_{2}$ concentrations decrease in this series of glasses. The two Frit 320-based glasses that target a lower WL (35\%) are based on the 1100 Canister Max Al, Na case (with and without ARP K). As the nomenclature implies, this SB4 blending option yields the highest $\mathrm{Na}_{2} \mathrm{O}$ content which allows lower WLs to be targeted yet still result in the classification of subject to nepheline formation using the "less conservative" 0.65 value.

Two Frit 418 based glasses fall into the "nepheline prone” region using the 0.65 value (i.e., Neph4 and Neph-8). Again, these two glasses are based on the 1100 Canister Max Al, Na blending option (with and without ARP K) and target the highest WL being evaluated (40\%). The lower $\mathrm{Na}_{2} \mathrm{O}$ concentration (8\%) in Frit 418 is off-set by the maximum $\mathrm{Na}_{2} \mathrm{O}$ from the particular blending option driving their discriminator values into the "prone" region using the less conservative 0.65 value.

It should be noted that only two glasses (Neph-01 and Neph-02) would be classified as "prone to nepheline formation" using the guideline or discriminator value (0.62) defined by Li et al. (2003). Again, these glasses are based on Frit 320 and the 1100 Canister Max Al, Na case and target a $40 \%$ WL which agree with theory regarding the potential for nepheline formation.

As previously mentioned, opening the assessment of potential nepheline formation issues to a larger matrix than would otherwise be implemented (i.e., using the less conservative 0.65 value) will provide valuable information to the frit selection process. More specifically, if one were to speculate on the experimental results several outcomes are possible. In one extreme case, nepheline formation is either not observed or, if present, it has little or no practical impact on the measured durability response. If these results were realized, then the frit selection process would not have to rule out the possible use of Frit 320 as a candidate for SB4. 
Another possible outcome would be that the Frit 320 - 1100 Canister Max $\mathrm{Al}$, Na cases (at 40\% and/or 35\% WL) did show the development of nepheline and a significant impact on the measured durability of the product. If this were true, then frit development efforts may have to recommend a frit with lower $\mathrm{Na}_{2} \mathrm{O}$ content (i.e., Frit 418 or some intermediate frit with $10 \%$ $\mathrm{Na}_{2} \mathrm{O}$ ) to avoid nepheline formation. Another option would be to ensure that the 1100 Canister Max Al, Na blending strategy (or an alternative strategy that resulted in a similar $\mathrm{Na}_{2} \mathrm{O}$ concentration) was not realized assuming Frit 320 was used. The response to these possible experimental outcomes is in-line with the "sliding $\mathrm{Na}_{2} \mathrm{O}$ scale" presented by Peeler and Edwards (2005a) for SB4. The only added insight into this overall strategy is not only to balance the $\mathrm{Na}_{2} \mathrm{O}$ contents from the frit and the sludge to maintain relatively large operating windows and enhanced melt rates, but also to avoid nepheline formation potential. A possible outcome of this balancing act would be that for a given SB4 blending option, the $\mathrm{Na}_{2} \mathrm{O}$ content of the frit may have to be lower to avoid nepheline formation which could have a negative impact on melt rate. If needed, further frit development efforts would strive to minimize any negative impacts to melt rate that result from lowering the $\mathrm{Na}_{2} \mathrm{O}$ content to avoid nepheline formation issues.

Table 4-1. The 48 SB4 Glasses as a Function of WL, Frit ID, Sludge Type and Nepheline Ratio.

\begin{tabular}{|c|c|c|c|}
\hline $\begin{array}{l}\text { WL } \\
(\%)\end{array}$ & $\begin{array}{c}\text { Frit } \\
\text { ID }\end{array}$ & Type & $\begin{array}{c}\text { Nepheline } \\
\text { Ratio }\end{array}$ \\
\hline 40 & 320 & 1100 Can Max Al, Na; Min Mn, Ni, U & 0.606 \\
\hline 40 & 320 & SB4 1100 Can Max Al, Na; Min Mn, Ni, U - App. K / ARP Stream & 0.608 \\
\hline 40 & 320 & SB4 1100 Can Baseline - App. K / ARP Stream & 0.637 \\
\hline 40 & 418 & 1100 Can Max Al, Na; Min Mn, Ni, U & 0.638 \\
\hline 40 & 320 & 1100 Can Baseline & 0.638 \\
\hline 40 & 320 & SB4 1100 Can Max Ni - App. K / ARP Stream & 0.639 \\
\hline 40 & 320 & 1100 Can Max Ni & 0.640 \\
\hline 40 & 418 & SB4 1100 Can Max Al, Na; Min Mn, Ni, U - App. K / ARP Stream & 0.640 \\
\hline 35 & 320 & 1100 Can Max Al, Na; Min Mn, Ni, U & 0.641 \\
\hline 40 & 320 & SB4 1100 Can Max Mg - App. K / ARP Stream & 0.641 \\
\hline 40 & 320 & 1100 Can Max Mg & 0.642 \\
\hline 35 & 320 & SB4 1100 Can Max Al, Na; Min Mn, Ni, U - App. K / ARP Stream & 0.643 \\
\hline 35 & 320 & SB4 1100 Can Baseline - App. K / ARP Stream & 0.670 \\
\hline 35 & 320 & 1100 Can Baseline & 0.671 \\
\hline 35 & 320 & SB4 1100 Can Max Ni - App. K / ARP Stream & 0.671 \\
\hline 40 & 418 & SB4 1100 Can Baseline - App. K / ARP Stream & 0.672 \\
\hline 35 & 320 & 1100 Can Max Ni & 0.672 \\
\hline 40 & 418 & 1100 Can Baseline & 0.673 \\
\hline 35 & 320 & SB4 1100 Can Max Mg - App. K / ARP Stream & 0.673 \\
\hline 40 & 418 & SB4 1100 Can Max Ni - App. K / ARP Stream & 0.674 \\
\hline 35 & 320 & 1100 Can Max Mg & 0.674 \\
\hline 30 & 320 & 1100 Can Max Al, Na; Min Mn, Ni, U & 0.675 \\
\hline 40 & 418 & 1100 Can Max Ni & 0.675 \\
\hline 35 & 418 & 1100 Can Max Al, Na; Min Mn, Ni, U & 0.676 \\
\hline 40 & 418 & SB4 1100 Can Max Mg - App. K / ARP Stream & 0.676 \\
\hline 30 & 320 & SB4 1100 Can Max Al, Na; Min Mn, Ni, U - App. K / ARP Stream & 0.677 \\
\hline
\end{tabular}


WSRC-TR-2005-00153

Revision 0

\begin{tabular}{||c|c|c|c||}
\hline $\begin{array}{c}\text { WL } \\
\text { (\%) }\end{array}$ & $\begin{array}{c}\text { Frit } \\
\text { ID }\end{array}$ & Type & $\begin{array}{c}\text { Nepheline } \\
\text { Ratio }\end{array}$ \\
\hline 40 & 418 & 1100 Can Max Mg & 0.677 \\
\hline 35 & 418 & SB4 1100 Can Max Al, Na; Min Mn, Ni, U - App. K / ARP Stream & 0.678 \\
\hline 30 & 320 & SB4 1100 Can Baseline - App. K / ARP Stream & 0.701 \\
\hline 30 & 320 & 1100 Can Baseline & 0.701 \\
\hline 30 & 320 & SB4 1100 Can Max Ni - App. K / ARP Stream & 0.702 \\
\hline 30 & 320 & 1100 Can Max Ni & 0.703 \\
\hline 30 & 320 & SB4 1100 Can Max Mg - App. K / ARP Stream & 0.703 \\
\hline 30 & 320 & SB4 1100 Can Baseline - App. K / ARP Stream & 0.704 \\
\hline 35 & 418 & 1100 Can Baseline & 0.706 \\
\hline 35 & 418 & SB4 1100 Can Max Ni - App. K / ARP Stream & 0.707 \\
\hline 35 & 418 & 1100 Can Max Ni & 0.708 \\
\hline 35 & 418 & SB4 1100 Can Max Mg - App. K / ARP Stream & 0.709 \\
\hline 35 & 418 & 1100 Can Max Mg & 0.710 \\
\hline 35 & 418 & 1100 Can Max Al, Na; Min Mn, Ni, U & 0.711 \\
\hline 30 & 418 & SB4 1100 Can Baseline - App. K / ARP Stream & 0.712 \\
\hline 30 & 418 & SB4 1100 Can Max Al, Na; Min Mn, Ni, U - App. K ARP Stream & 0.714 \\
\hline 30 & 418 & SB4 1100 Can Max Ni - App. K / ARP Stream & 0.739 \\
\hline 30 & 418 & 1100 Can Max Ni & 0.740 \\
\hline 30 & 418 & SB4 1100 Can Max Mg - App. K / ARP Stream & 0.741 \\
\hline 30 & 418 & 1100 Can Max Mg & 0.741 \\
\hline 30 & 418 & & 0.742 \\
\hline 30 & 418 & & 0.743 \\
\hline
\end{tabular}


WSRC-TR-2005-00153

Revision 0

Table 4-2. Target Glass Compositions (in wt\%) for the Nepheline Formation Study (Neph01 through Neph-06).

\begin{tabular}{|c|c|c|c|c|c|c|}
\hline Glass ID & Neph-01 & Neph-02 & Neph-03 & Neph-04 & Neph-05 & Neph-06 \\
\hline WL (\%) & 40 & 40 & 40 & 40 & 40 & 40 \\
\hline Frit ID & 320 & 320 & 320 & 418 & 320 & 320 \\
\hline Feed Type & $\begin{array}{l}1100 \text { Can } \\
\text { Max Al, } \\
\text { Na; Min } \\
\text { Mn, Ni, U }\end{array}$ & $\begin{array}{l}\text { SB4 } 1100 \text { Can } \\
\text { Max Al, Na; } \\
\text { Min Mn, Ni, U } \\
\text { + ARP K }\end{array}$ & $\begin{array}{l}\text { SB4 1100 } \\
\text { Can Baseline } \\
\text { + ARP K }\end{array}$ & $\begin{array}{c}1100 \text { Can } \\
\text { Max Al, Na; } \\
\text { Min Mn, Ni, } \\
\text { U }\end{array}$ & $\begin{array}{l}1100 \text { Can } \\
\text { Baseline }\end{array}$ & $\begin{array}{c}\text { SB4 1100 } \\
\text { Can Max Ni } \\
+ \text { ARP K }\end{array}$ \\
\hline $\mathrm{Al}_{2} \mathrm{O}_{3}$ & 12.612 & 11.683 & 8.467 & 12.612 & 9.070 & 8.375 \\
\hline $\mathrm{B}_{2} \mathrm{O}_{3}$ & 4.800 & 4.800 & 4.800 & 4.800 & 4.800 & 4.800 \\
\hline $\mathrm{BaO}$ & 0.043 & 0.042 & 0.062 & 0.043 & 0.065 & 0.076 \\
\hline $\mathrm{CaO}$ & 0.884 & 0.839 & 0.848 & 0.884 & 0.893 & 0.723 \\
\hline $\mathrm{Ce}_{2} \mathrm{O}_{3}$ & 0.082 & 0.081 & 0.082 & 0.082 & 0.083 & 0.077 \\
\hline $\mathrm{Cr}_{2} \mathrm{O}_{3}$ & 0.092 & 0.087 & 0.096 & 0.092 & 0.101 & 0.105 \\
\hline $\mathrm{CuO}$ & 0.029 & 0.028 & 0.032 & 0.029 & 0.034 & 0.032 \\
\hline $\mathrm{Fe}_{2} \mathrm{O}_{3}$ & 9.087 & 8.701 & 9.897 & 9.087 & 10.404 & 9.240 \\
\hline $\mathrm{K}_{2} \mathrm{O}$ & 0.682 & 0.624 & 0.377 & 0.682 & 0.410 & 0.416 \\
\hline $\mathrm{La}_{2} \mathrm{O}_{3}$ & 0.034 & 0.034 & 0.036 & 0.034 & 0.037 & 0.034 \\
\hline $\mathrm{Li}_{2} \mathrm{O}$ & 4.800 & 4.800 & 4.800 & 4.800 & 4.800 & 4.800 \\
\hline $\mathrm{MgO}$ & 0.732 & 0.669 & 0.710 & 0.732 & 0.777 & 0.424 \\
\hline $\mathrm{MnO}$ & 1.913 & 1.905 & 2.289 & 1.913 & 2.335 & 2.352 \\
\hline $\mathrm{Na}_{2} \mathrm{O}$ & 16.348 & 16.987 & 16.682 & 13.948 & 16.011 & 16.504 \\
\hline $\mathrm{NiO}$ & 0.583 & 0.579 & 1.400 & 0.583 & 1.486 & 2.254 \\
\hline $\mathrm{PbO}$ & 0.081 & 0.078 & 0.065 & 0.081 & 0.066 & 0.063 \\
\hline $\mathrm{SO}_{4}$ & 0.442 & 0.508 & 0.506 & 0.442 & 0.439 & 0.504 \\
\hline $\mathrm{SiO}_{2}$ & 44.482 & 44.389 & 44.218 & 46.882 & 44.293 & 44.055 \\
\hline $\mathrm{ThO}_{2}$ & 0.020 & 0.018 & 0.013 & 0.020 & 0.014 & 0.011 \\
\hline $\mathrm{TiO}_{2}$ & 0.010 & 0.979 & 0.977 & 0.010 & 0.009 & 0.975 \\
\hline $\mathrm{U}_{3} \mathrm{O}_{8}$ & 2.111 & 2.036 & 3.489 & 2.111 & 3.711 & 4.013 \\
\hline $\mathrm{ZnO}$ & 0.040 & 0.039 & 0.049 & 0.040 & 0.051 & 0.050 \\
\hline $\mathrm{ZrO}_{2}$ & 0.095 & 0.094 & 0.109 & 0.095 & 0.112 & 0.120 \\
\hline $\begin{array}{c}\text { Nepheline } \\
\text { Discriminator }\end{array}$ & 0.606 & 0.608 & 0.637 & 0.638 & 0.638 & 0.639 \\
\hline
\end{tabular}


WSRC-TR-2005-00153

Revision 0

Table 4-2 (continued). Target Glass Compositions (in wt \%) for the Nepheline Formation Study (Neph-07 through Neph-12).

\begin{tabular}{|c|c|c|c|c|c|c|}
\hline Row \# & Neph-07 & Neph-08 & Neph-09 & Neph-10 & Neph-11 & Neph-12 \\
\hline WL (\%) & 40 & 40 & 35 & 40 & 40 & 35 \\
\hline Frit ID & 320 & 418 & 320 & 320 & 320 & 320 \\
\hline Feed Type & $\begin{array}{c}1100 \\
\text { Can } \\
\text { Max Ni }\end{array}$ & $\begin{array}{c}\text { SB4 1100 } \\
\text { Can Max } \\
\text { Al, Na; Min } \\
\text { Mn, Ni, U + } \\
\text { ARP K }\end{array}$ & $\begin{array}{l}1100 \text { Can } \\
\text { Max Al, } \\
\text { Na; Min } \\
\text { Mn, Ni, U }\end{array}$ & $\begin{array}{c}\text { SB4 1100 Can } \\
\text { Max Mg + } \\
\text { ARP K }\end{array}$ & $\begin{array}{l}1100 \text { Can } \\
\text { Max Mg }\end{array}$ & $\begin{array}{c}\text { SB4 } 1100 \\
\text { Can Max Al, } \\
\text { Na; Min Mn, } \\
\text { Ni, U + ARP } \\
\text { K }\end{array}$ \\
\hline $\mathrm{Al}_{2} \mathrm{O}_{3}$ & 8.969 & 11.683 & 11.035 & 8.097 & 8.664 & 10.222 \\
\hline $\mathrm{B}_{2} \mathrm{O}_{3}$ & 4.800 & 4.800 & 5.200 & 4.800 & 4.800 & 5.200 \\
\hline $\mathrm{BaO}$ & 0.080 & 0.042 & 0.038 & 0.062 & 0.065 & 0.037 \\
\hline $\mathrm{CaO}$ & 0.756 & 0.839 & 0.774 & 0.859 & 0.905 & 0.734 \\
\hline $\mathrm{Ce}_{2} \mathrm{O}_{3}$ & 0.078 & 0.081 & 0.072 & 0.081 & 0.083 & 0.071 \\
\hline $\mathrm{Cr}_{2} \mathrm{O}_{3}$ & 0.111 & 0.087 & 0.080 & 0.094 & 0.100 & 0.076 \\
\hline $\mathrm{CuO}$ & 0.034 & 0.028 & 0.025 & 0.032 & 0.033 & 0.024 \\
\hline $\mathrm{Fe}_{2} \mathrm{O}_{3}$ & 9.680 & 8.701 & 7.951 & 10.088 & 10.613 & 7.613 \\
\hline $\mathrm{K}_{2} \mathrm{O}$ & 0.454 & 0.624 & 0.597 & 0.334 & 0.363 & 0.546 \\
\hline $\mathrm{La}_{2} \mathrm{O}_{3}$ & 0.035 & 0.034 & 0.030 & 0.036 & 0.037 & 0.029 \\
\hline $\mathrm{Li}_{2} \mathrm{O}$ & 4.800 & 4.800 & 5.200 & 4.800 & 4.800 & 5.200 \\
\hline $\mathrm{MgO}$ & 0.462 & 0.669 & 0.641 & 0.784 & 0.859 & 0.585 \\
\hline $\mathrm{MnO}$ & 2.404 & 1.905 & 1.674 & 2.387 & 2.443 & 1.667 \\
\hline $\mathrm{Na}_{2} \mathrm{O}$ & 15.816 & 14.587 & 15.805 & 16.659 & 15.987 & 16.364 \\
\hline $\mathrm{NiO}$ & 2.426 & 0.579 & 0.510 & 1.425 & 1.514 & 0.507 \\
\hline $\mathrm{PbO}$ & 0.064 & 0.078 & 0.071 & 0.062 & 0.063 & 0.068 \\
\hline $\mathrm{SO}_{4}$ & 0.438 & 0.508 & 0.386 & 0.506 & 0.439 & 0.444 \\
\hline $\mathrm{SiO}_{2}$ & 44.114 & 46.789 & 47.921 & 44.225 & 44.301 & 47.840 \\
\hline $\mathrm{ThO}_{2}$ & 0.012 & 0.018 & 0.017 & 0.012 & 0.014 & 0.016 \\
\hline $\mathrm{TiO}_{2}$ & 0.006 & 0.979 & 0.009 & 0.978 & 0.009 & 0.856 \\
\hline $\mathrm{U}_{3} \mathrm{O}_{8}$ & 4.287 & 2.036 & 1.847 & 3.528 & 3.753 & 1.781 \\
\hline $\mathrm{ZnO}$ & 0.052 & 0.039 & 0.035 & 0.048 & 0.050 & 0.035 \\
\hline $\mathrm{ZrO}_{2}$ & 0.124 & 0.094 & 0.083 & 0.105 & 0.107 & 0.082 \\
\hline $\begin{array}{l}\text { Nepheline } \\
\text { Discriminator }\end{array}$ & 0.64 & 0.64 & 0.641 & 0.641 & 0.642 & 0.643 \\
\hline
\end{tabular}


WSRC-TR-2005-00153

Revision 0

\subsection{EXPERIMENTAL}

Each glass will be prepared from the proper proportions of reagent-grade metal oxides, carbonates, $\mathrm{H}_{3} \mathrm{BO}_{3}$, and salts in 150-g batches. Once batched (SRNL 2002a), the glasses will be melted using Savannah River National Laboratory (SRNL) technical procedure "Glass Melting" (SRNL 2002b). In general, the raw materials will be thoroughly mixed and placed into a 95\% Platinum/5\% Gold 250 -mL crucible. The batch will be placed into a high-temperature furnace at the target melt temperature of $1150^{\circ} \mathrm{C}$. After an isothermal hold at $1150^{\circ} \mathrm{C}$ for $1.0 \mathrm{~h}$, the crucible will be removed, and the glass poured onto a clean stainless steel plate and allowed to air cool. The pour patty will be used as a sampling stock for the various property measurements (i.e., chemical composition and durability).

To bound the effects of thermal history on the product performance, approximately $25 \mathrm{~g}$ of each glass will be heat treated to simulate cooling along the centerline of a DWPF-type canister (Marra and Jantzen 1993). This cooling regime is commonly referred to as the centerline canister cooled (сcс) curve.

\subsection{Compositional Analysis}

To confirm that the "as-fabricated" glasses correspond to the defined target compositions, a representative sample from each glass pour patty will be submitted to the SRNL Mobile Laboratory (SRNL-ML) for chemical analysis under the auspices of an analytical plan. The plan will identify the cations to be analyzed and the dissolution techniques (i.e., sodium peroxide fusion [PF] and lithium-metaborate [LM]) to be used. Each glass will be prepared in duplicate for each cation dissolution technique (PF and LM). Concentrations (as mass \%) for the cations of interest will be measured by inductively coupled plasma - atomic emission spectroscopy (ICP AES). The analytical plan will be developed in such a way as to provide the opportunity to evaluate potential sources of error. Glass standards will be intermittently run to assess the performance of the ICP - AES over the course of these analyses.

\subsection{Product Consistency Test (PCT)}

The PCT will be performed in triplicate on each quenched and ccc "Neph" glass to assess chemical durability using technical procedure "Standard Test Methods for Determining Chemical Durability of Nuclear Waste Glasses: The Product Consistency Test (PCT)” (ASTM 2002). Also included in this experimental test matrix will be the Environmental Assessment (EA) glass (Jantzen et al. 1993), the Approved Reference Material (ARM) glass, and blanks from the sample cleaning batch. Samples will be ground, washed, and prepared according to procedure (ASTM 2002). Fifteen milliliters of Type I American Society for Testing and Materials (ASTM) water will be added to $1.5 \mathrm{~g}$ of glass in stainless steel vessels. The vessels will be closed, sealed, and placed in an oven at $90 \pm 2^{\circ} \mathrm{C}$ where the samples will be maintained for 7 days. The resulting solutions (once cooled) will be sampled (filtered and acidified), labeled (according to the analytical plan), and analyzed under the auspices of an analytical plan. The overall philosophy of the plan will be to provide an opportunity to assess the consistency (repeatability) of the PCT and analytical procedures in an effort to evaluate chemical durability of the "Neph" glasses. Normalized release rates will be calculated based on targeted, measured, and bias-corrected compositions using the average of the logs of the leachate concentrations. 
WSRC-TR-2005-00153

Revision 0

\subsection{SUMMARY}

The effect of crystallization on glass durability is complex and depends on several interrelated factors including the change in residual glass composition, the formation of internal stress or microcracks, and the preferential attack at the glass-crystal interface. Perhaps one of the most significant effects is the type and extent (or fraction) of crystallization and the change to the residual glass composition. A strong increase in glass dissolution (or decrease in durability) has been observed in previous studies in glasses that formed aluminum-containing crystals, such as $\mathrm{NaAlSiO}_{4}$ (nepheline) and $\mathrm{LiAlSi}_{2} \mathrm{O}_{6}$, and crystalline $\mathrm{SiO}_{2}$.

Although the addition of $\mathrm{Al}_{2} \mathrm{O}_{3}$ to borosilicate glasses enhances the durability of the waste form (through creation of network-forming tetrahedral $\mathrm{Na}^{+}-\left[\mathrm{AlO}_{4 / 2}\right]^{-}$pairs), the combination of high $\mathrm{Al}_{2} \mathrm{O}_{3}$ and $\mathrm{Na}_{2} \mathrm{O}$ can lead to the formation of nepheline $\left(\mathrm{NaAlSiO}_{4}\right)$. Given the projected high concentration of $\mathrm{Al}_{2} \mathrm{O}_{3}$ in SB4 and the potential use of a high $\mathrm{Na}_{2} \mathrm{O}$ based frit to improve melt rate, the potential formation of nepheline in various SB4 systems is being assessed. Li et al. (2003) indicate that sodium alumino-borosilicate glasses are prone to nepheline crystallization if their compositions projected on the $\mathrm{Na}_{2} \mathrm{O}-\mathrm{Al}_{2} \mathrm{O}_{3}-\mathrm{SiO}_{2}$ ternary fall within or close to the nepheline primary phase field in the $\mathrm{Na}_{2} \mathrm{O}-\mathrm{Al}_{2} \mathrm{O}_{3}-\mathrm{SiO}_{2}$ phase diagram. In particular, durable glasses with $\mathrm{SiO}_{2} /\left(\mathrm{SiO}_{2}+\mathrm{Na}_{2} \mathrm{O}+\mathrm{Al}_{2} \mathrm{O}_{3}\right)>0.62$, where the chemical formula stand for the mass fractions in the glass, do not precipitate nepheline as their primary phase.

Forty-eight SB4 glass compositions were screened using the nepheline discriminator to assess the potential formation of nepheline. The 48 glasses were based on four specific blending scenarios as defined by Lilliston (2005) [(1) 1100 Can Baseline, (2) 1100 Can Max Al, Na; Min Mn, Ni, (3) 1100 Can Max Mg, and (4) 1100 Can Max Ni] and the use of Frit 418 and Frit 320. The use of the 1100 Can Baseline option provides a central comparison point as this option currently serves as the baseline flowsheet for SB4. The use of these different flowsheets also provides compositional variation from which the formation of nepheline can be evaluated. For example, the 1100 Can Max Al, Na case will be an interesting option as this case increases both $\mathrm{Al}_{2} \mathrm{O}_{3}$ and $\mathrm{Na}_{2} \mathrm{O}$ concentrations in glass as waste loadings are increased. In addition, knowing that the primary source of $\mathrm{SiO}_{2}$ stems from the frit, as WLs increase the $\mathrm{SiO}_{2}$ content of the glass decreases - increasing the probability of nepheline formation according to the discriminator developed by Li et al. (2003). Based on that theory, the probability of nepheline formation should increase as high-alkali frits are used and should further increase with higher WLs.

Only two (Neph-01 and Neph-02) of the 48 glasses were classified as "prone to nepheline formation" using the guideline or discriminator value (0.62). These glasses are based on Frit 320 and the 1100 Canister Max Al, Na case and target a 40\% WL, which agree with theory regarding the potential for nepheline formation. Although Li et al. (2003) define the "line of demarcation" between glasses that are prone to nepheline formation from those that are not based on a value of 0.62 , that line may be somewhat ill-defined. Therefore, to provide a higher probability of observing the formation of nepheline and the potential negative impact on durability, a value of 0.65 was used to establish the glasses to be tested in this study. Twelve glasses were identified or classified as "prone to nepheline" formation using this "less conservative" value which will be fabricated and tested. Using the "less conservative" value will not only increase the probability of forming nepheline but will also allow the assessment of several different blending scenarios, both frits (Frit 320 and Frit 418), and different WLs which will provide valuable insight into the frit selection process for SB4. More specifically, blending strategies, frit compositions, and WLs that avoid nepheline formation could be used to guide the frit selection process or to make compositional adjustments to the frit. 
WSRC-TR-2005-00153

Revision 0

The twelve nepheline glasses will be fabricated using standard procedures. The durability of these 12 glasses (of both quenched and centerline canister cooled versions) will be measured with the results being documented in a subsequent report.

\subsection{REFERENCES}

ASTM 2002. Standard Test Methods for Determining Chemical Durability of Nuclear Waste Glasses: The Product Consistency Test (PCT), ASTM C-1285-2002.

Bickford, D.F. and CM Jantzen. 1984. “Devitrification of SRL Defense Waste Glass”, Sci. Basis for Nuclear Waste Management, VII, G.L. McVay (ed). Elsevier Publ., New York, 557-565.

Bickford, D.F. and CM Jantzen. 1986. "Devitrification of Defense Nuclear Waste Glasses: Role of Melt Insolubles”, J. Non-Crystalline Solids, 84 [1-3] 299-307.

Brown KG, CM Jantzen, and G Ritzhaupt. 2001. Relating Liquidus Temperature to Composition for Defense Waste Processing Facility (DWPF) Process Control, WSRC-TR-2001-00520, Westinghouse Savannah River Company, Aiken, South Carolina.

Jantzen, CM, DF Bickford, DG Karraker, and GG Wicks. 1984. “Time-TemperatureTransformation Kinetics in SRL Waste Glass”, Advances in Ceramics, Volume 8, American Ceramic Society, Westerville, OH, 30-38.

Jantzen, CM, NE Bibler, DC Beam, CL Crawford, and MA Pickett. 1993. Characterization of the Defense Waste Processing Facility (DWPF) Environmental Assessment (EA) Glass Standard Reference Material, WSRC-TR-92-346, Revision 1, Westinghouse Savannah River Company, Aiken, South Carolina.

Jantzen, CM and DF Bickford. 1985. "Leaching of Devitrified Glass Containing Simulated SRP Nuclear Waste”, Sci. Basis for Nuclear Waste Management, VIII, C.M. Jantzen, J.A. Stone and R.C. Ewing (eds.), Materials Research Society, Pittsburgh, PA 135-146.

Kim, DS, DK Peeler, and P Hrma. 1995. "Effect of Crystallization on the Chemical Durability of Simulated Nuclear Waste Glasses”, Environmental Issues and Waste Management Technologies in the Ceramic and Nuclear Industries, Ceramic Transaction, Volume 61, pp. 177 185.

Li, H, JD Vienna, P Hrma, DE Smith, and MJ Schwieger. 1997. "Nepheline Precipitation in High-Level Waste Glasses - Compositional Effects and Impact on the Waste Form Acceptability”, Mat. Res. Soc. Proc. 465, 261- 268.

Li, H, P Hrma, JD Vienna, M Qian, Y Su, and DE Smith. 2003. "Effects of $\mathrm{Al}_{2} \mathrm{O}_{3}, \mathrm{~B}_{2} \mathrm{O}_{3}, \mathrm{Na}_{2} \mathrm{O}$, and $\mathrm{SiO}_{2}$ on Nepheline Formation in Borosilicate Glasses: Chemical and Physical Correlations", Journal of Non-Crystalline Solids, 331 (2003) 202 - 216.

Lilliston, GR. 2005. Development of Elemental Sludge Compositions for Variations of Sludge Batch 4 (SB4), CBU-PIT-2004-00011, Revision 1, Westinghouse Savannah River Company, Aiken, South Carolina. 
Marra SL and CM Jantzen. 1993. Characterization of Projected DWPF Glass Heat Treated to Simulate Canister Centerline Cooling, WSRC-TR-92-142, Revision 1, Westinghouse Savannah River Company, Aiken, South Carolina.

Peeler, DK and TB Edwards. 2003. Projected Opeating Windows for Various Sludge Batch 2/3 Blends: A Progression from a PAR to a MAR Assessment, WSRC-TR-2003-00509, Revision 0, Westinghouse Savannah River Company, Aiken, South Carolina.

Peeler, DK and TB Edwards. 2005a. Frit Development Efforts for Sludge Batch 4 (SB4): ModelBased Assessments, WSRC-TR-2005-00103, Revision 0, Westinghouse Savannah River Company, Aiken, South Carolina.

Peeler DK and TB Edwards. 2005b. A Preliminary Assessment of the Need for a Sludge Batch 4 Variability Study, WSRC-TR-2005-00122, Revision 0, Westinghouse Savannah River Company, Aiken, South Carolina.

Peeler DK and TB Edwards. 2005c. The Impact of the Actinide Removal Process (ARP) on the SB4 Projected Operating Windows, WSRC-TR-2005-00123, Revision 0, Westinghouse Savannah River Company, Aiken, South Carolina.

Riley, BJ, JA Rosario, and P Hrma. 2001. Impact of HLW Glass Crystallinity on the PCT Response, PNNL-13491, Pacific Northwest National Laboratory, Richland, Washington.

Spilman, DB, LL Hench, DE Clark. 1986. "Devitrification and Subsequent Effects on the Leach Behavior of a Simulated Borosilicate Nuclear Waste Glass”, Nuclear and Chemical Waste Management, Vol.6, pp. 107 - 119 (1986).

Savannah River National Laboratory (SRNL). 2002a. “Glass Batching,” SRTC Procedure Manual, L29, ITS-0001, Westinghouse Savannah River Company, Aiken, South Carolina.

Savannah River National Laboratory (SRNL). 2002b. “Glass Melting,” SRTC Procedure Manual, L29, ITS-0003, Westinghouse Savannah River Company, Aiken, South Carolina.

Stone, ME and JE Josephs. 2001. Melt Rate Improvement for DWPF MB3: Melt Rate furnace Testing, WSRC-TR-2001-00146, Revision 0, Westinghouse Savannah River Company, Aiken, South Carolina. 


\section{Distribution:}

E.W. Holtzscheiter, 773-A

D.A. Crowley, 999-W

S.L. Marra, 999-W

T.B. Calloway, 999-W

N.E. Bibler, 773-A

C.M. Jantzen, 773-A

J.R. Harbour, 773-42A

G.G. Wicks, 773-A

D.K. Peeler, 999-W

T.B. Edwards, 773-42A

C.C. Herman, 773-42A

T.H. Lorier, 773-A

M.E. Smith, 773-42A
M.E. Stone, 999-W

M.S. Miller, 704-S

J.E. Occhipinti, 704-S

R.M. Hoeppel, 704-27S

J.F. Iaukea, 704-30S

J.W. Ray, 704-S

F.A. Washburn, 704-28S

A.V. Staub, 704-27S

H.H. Elder, 766-H

D.C. Bumgardner, 766-H

J.M. Gillam, 766-H

W.B. Van Pelt, 704-S

H.B. Shah, 766-H 